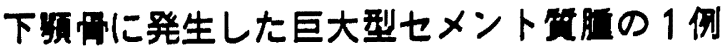

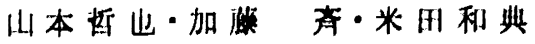

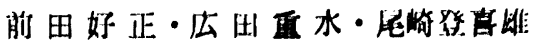

\section{Giantiform cementoma of the mandible: A case report}

\author{
Tetsuya Yamamoto - Itsuki Kato - Kazunori Yoneda \\ Yoshimasa Maeda - Jusui Hirota - Tokio Osakı
}

\begin{abstract}
Giantiform cementoma, a type of cementoma accorded to the WHO clasifiction in 1971, is rarely seen in the literatures. A case of this tumor is reported with a summary as follows. A bony swelling as found on the body and ramus of the mandible of a refered 83year-old woman. The smooth expansion covered with normal mucosa has persisted for about $40 \mathrm{yrs}$ and slowly enlarged with no symptoms. In $\mathrm{X}$-ray showed a demarcated radiopaque shadow with parts slightly radiolucent. The shadow seemed to be capsulated with healthy thin cortex. This was thought to be a benign tumor. A block dissection of the mandible was made. The dissected tumor was extremely hard with a yellowish cut-surface. The decarcified specimen was stained with H.E. for a subsequent microscopic examination.

Connective tissue and infiltrated cells were nearly absent. In the central portion, basophilic hard tissue had formed and seemed to be primary cementum in such characteristics as dyeing fatigue and split spaces with no inclusion of cells. At the peripheral, and coexistence of the bone, fibrous and fat tissues could be seen. Substitution of bone by cementum and formation of cemeticles showing hematoxylin-line were also observed. On the basis of the above findings, a diagnosis of giantiform cementoma of the mandible was made.
\end{abstract}

Key words: giantiform cementoma, mandible

緒

\section{쿰}

セメント質腫は中胚葉系の組織に由来し，セメント質

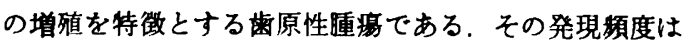
比較的少なく，臨床的・病理組織学的に種々の様相を呈 するが，現在，セメント質畽は，1971 年のWHO の分 類により，良性セメント芽細胞腫，セメント質形成線稚 睡，根尖性セメント質異形成症，巨大型セメント質に分 類されている。なかです，Gorlin ら゙より提唱された 巨大型セメント質腫は，原生セメント質に似た硬組織が 多量に形成され，しぱしば著しい大きさに達するきわめ

高知医科大学医学部附属病院歯科口腔外科

（主任：尾崎登喜雄教授）

Kochi Medical School Department of Oral Surgery (Chief: Prof. Tokio Osaki)

受付日：昭和62年 1 月 9 日

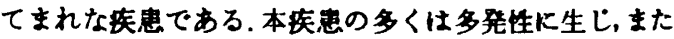
家族性に発生することるあるため，家族性多発性セメン ト質尰の別名が付記されている。

今回，われわれは83成の女性の下預骨に発生した，長 期の病璴を有する非常に大きな単発性の巨大型セメント 筫隀の 1 例を経検したので，その㯕要を報告する。

\section{症例}

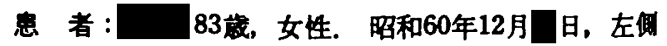
下影臼齿部の隀脹・疼痛を主訴に来院.

病 厢：家族憷，既往歴に特記事須はなく，現病歴と しては，昭和20年頃より，左僋下額大日歯部に小さな尰 慮を認めていたが無痛性のため放居していた。 その後， 腫慮は徐々に增大傾向を示し，昭和60年 9 月頃より，同 患部に軽度の自発痛を認めるようになったため，同年11 月某歯科医院を受診し，当科を稆介され来院した。 


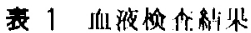

\begin{tabular}{|c|c|c|c|}
\hline RIBC & $153 \times 101 / 101$ & $\gamma-1 ; 1)$ & $81 . \mathrm{U} . / l$ \\
\hline $\mathrm{Ht}$ & $13.00_{0}$ & T'-Bil & $0.4 \mathrm{ng} / \mathrm{dl}$ l \\
\hline $\mathrm{Hb}$ & $12.8 \mathrm{~g} / \mathrm{d} l$ & () Bil & $0.1 \mathrm{mg} / \mathrm{d} l$ \\
\hline 'Thrombo & 16. $2 \times 101 / \mu l$ & (h): & $307 \mathrm{I}, 11 . / \mathrm{d} l$ \\
\hline WBC: & $6.7 \times 10^{3} / \mu l$ & $\left(: \mathrm{I}^{2} \mathrm{I}^{\prime}\right.$ & $61.11 . / 1$ \\
\hline \multirow[t]{2}{*}{ Bleeding Time } & 3.0 min & $(i))^{2}$ & $13 \mathrm{~J} . \mathrm{U} . / \mathrm{l}$ \\
\hline & & $1.1) 11$ & $342 \mathrm{I}, \mathrm{U} . / l$ \\
\hline TP & $6.1 \mathrm{~g} / \mathrm{d} l$ & $B U N$ & $23 \mathrm{mg} / \mathrm{d} l$ \\
\hline $\mathrm{Alb}$ & $3.6 \mathrm{~g} / \mathrm{d} l$ & $\mathrm{Na}$ & 137 ו1:1// \\
\hline LAP & 34 I.U./l & $\mathbf{K}$ & $4.2 \mathrm{mE} / \mathrm{l} / \mathrm{l}$ \\
\hline AIP & 194 I.U./l & ( 1 & $99 \mathrm{nul}$ (id $/ l$ \\
\hline
\end{tabular}

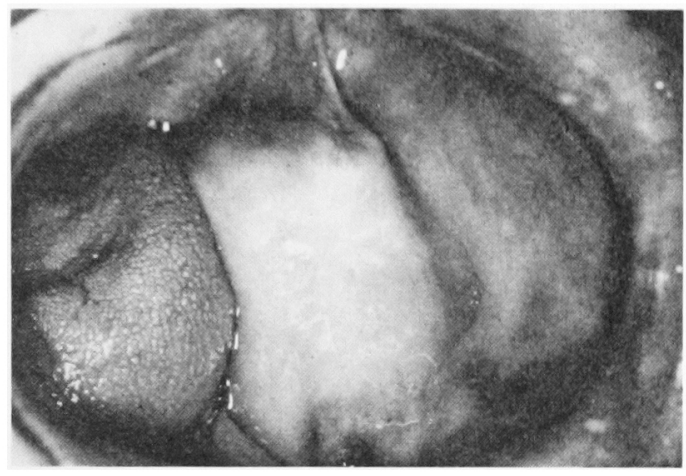

写真 1 術前口腔内

下顎左側小田相相当部より左側下颚枝にかけて，小 児手掱大・骨様硬の膨隆を諗める。

現 症：体格中等度，高踰にもかかわらす゚健常な日常 生活を営み学荺状態良好で, 通則の血液検査においてす 異常なく（表1），全身的に特記すべき事項は認められ なかった，局所についてみると，顔貌は左右非対称で，

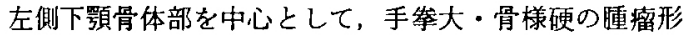
成を認めた。患部は非圧痛性で，患部の皮膚，所属りン パ節に特別の所見は認められなかった，口腔内は，上下

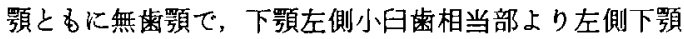
枝にかけて，小刓手拳大で骨様硬の，表面が比較的滑沢 な膨隆を認めた（写真１）。同部被覆粘膜は正常で，開 口障害, 口唇の知覚異常・麻㽻等は認められなかった。 X楾写真に扎いて，下顎左側小目歯部より左側下顎枝に かけて手杽大で散在性に透過像を伴った，やや不均一な 不透過像を認め，その外側に菲薄化した周囲皮質骨が一 部に認められた（写真 $2 ， 3 ）$. 不透過像と正常骨上の 䔟行は比較的明確であった。

以上のような，臨床経過ならびに所見および入稍像よ

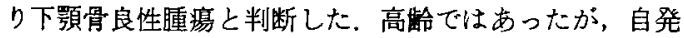
痛が生じてきたこと执び腫瘤が大であったことより病 果を切除することとした。

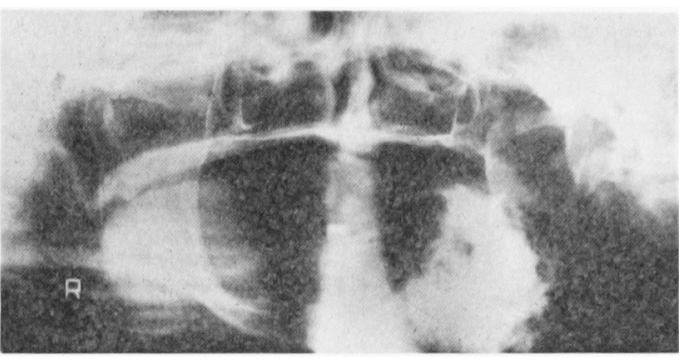

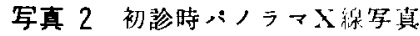
下䫎左側小四部上り左側下䫇枝にかけて散在性に 透猧像を伴った，辺释がや中不均一な不透過像を認 める。 その外僋には翡溥化した周瞳皮質骨を琵め る。

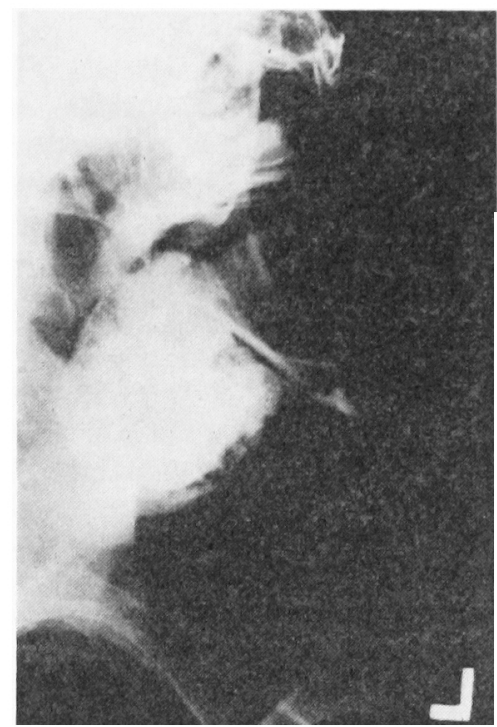

写真 3 初診時下顎骨斜位X線军真 


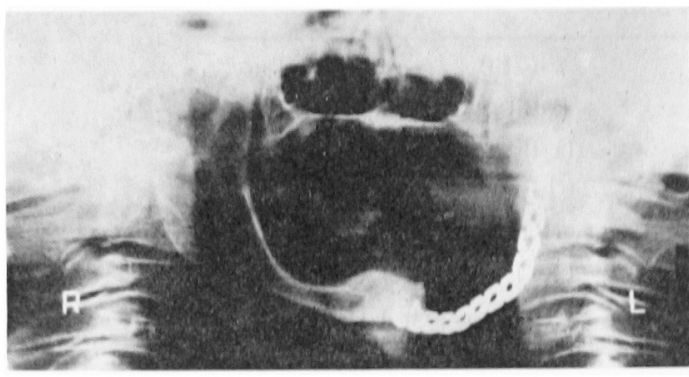

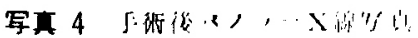

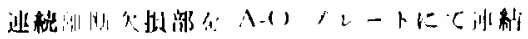

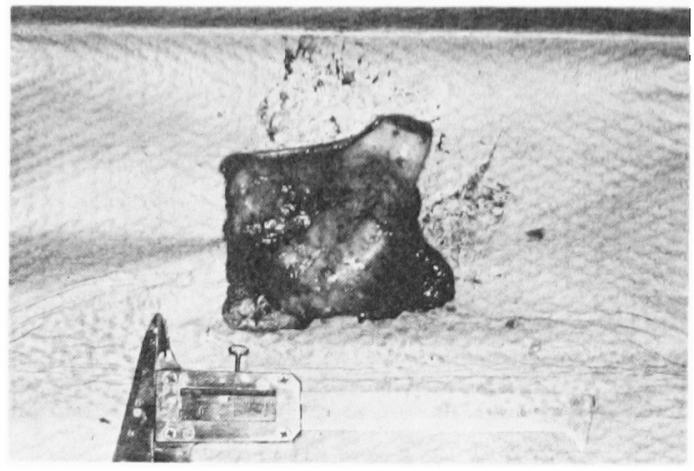

写真 5 摘出物

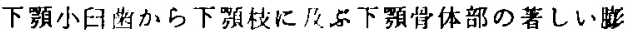

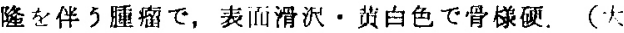
きさ $5.2 \times 5.0 \times 4.4 \mathrm{~cm}$ 全重量的 $120 \mathrm{~g}$ )

治療および経過：炤和 60 年 12 月日日 入院後, 同 日 G.O.F. 全身庥蠤下に，下䫑骨区域切除による随㻛摘出 扣よび下影骨再建衍を施行した，通法に従い下䫑骨を剖 出すると，表面がやや黄色の骨様硬の腫䇶が，オトガイ 孔より下顎枝上方まで認められた，腫溜と骨膜の陡着は なく，骨膜の制離は容易であった，健康な下䫑頭・笳塋 起は保存すへく，下䂓切㾴より約 $1.5 \mathrm{~cm}$ 下方で切離 L，近心侧は左侧第 1 小四齿相当部にて切離し腫瘤を摘 出した。摘出後，欠損部は $\mathrm{A}-\mathrm{O} フ ゚$ プレトにて連結した (写真 4).

摘出物所見: 摘出物は，大きさ $5.2 \times 5.0 \times 4.4 \mathrm{~cm}$ ，

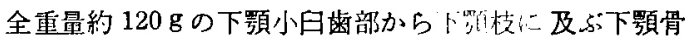
体部の著しい膨隆を伴う尰瘤で，表面は滑沢，黄白色で 骨様硬であった（写真 5 ）、崡科用タービン・ダイヤモ ンドポイントにより割を入れると，厚さ約 $5 \mathrm{~mm}$, 黄白 色の緻泌骨と思われる硬組織に囲まれた，黄色で充実性 の硬性な組種が認められた（写真 6 ).

病理組織学的所見：摘出物を脱灭後，H.E. 染色:て 鏡娭した，全体的には線䧽性結合織はそしく，細胞浸潤 も認められず，腫瘤中心部では，Hematoxylinに好染す る比較的均一な原性セメント質に類似した硬組織の増生

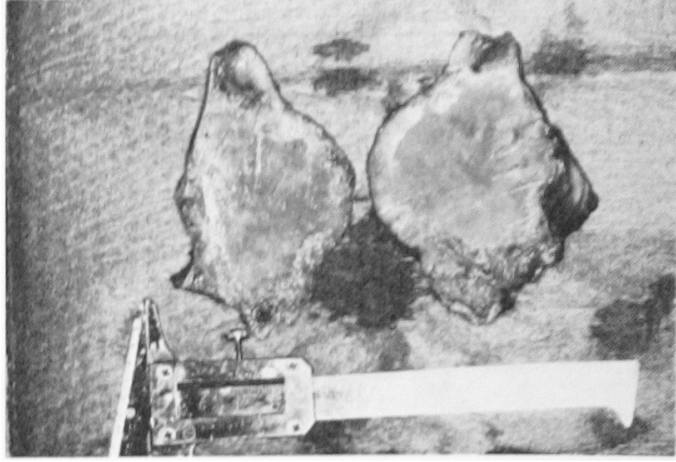

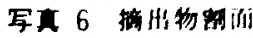

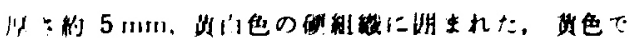

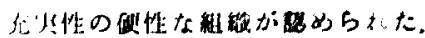

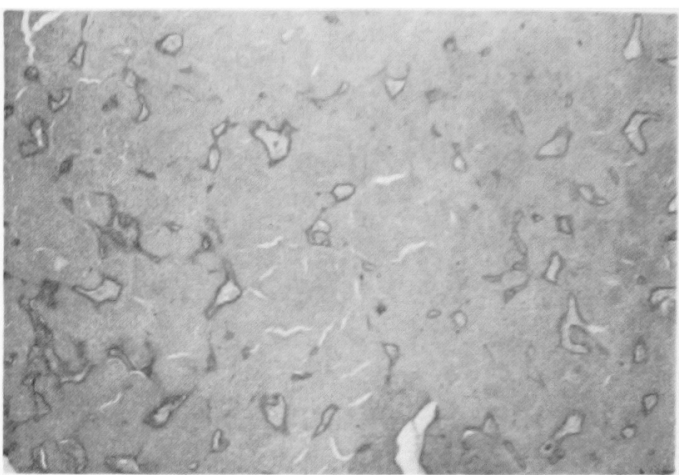

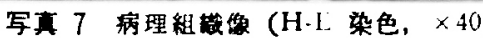

IIcmatoxylin に好染する比的一大原生七火ン

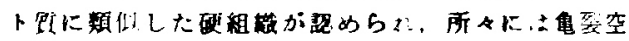

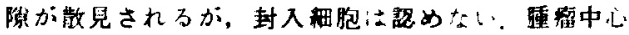
部)

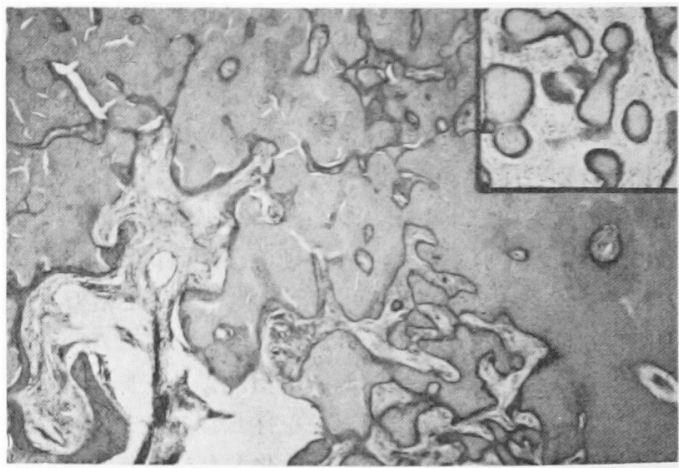

写南 8 病理組織 (H-E 染色, $\times 40$ )

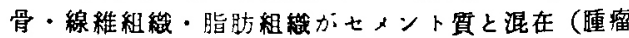
辺緑部)

が認められた．所々には豊裂空腺が散見され，セメント 小腔棈造に類似していたが，その膑内には封入細胞忹 められなかった（写真 7). 一方, 辺縁部ては, 骨・線維 


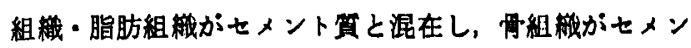
ト賽に正換されているところる見られ，また，Hema-

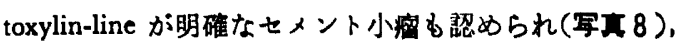
骨・線維組織が中心部上り辺粶部にかけ徐々にセメント

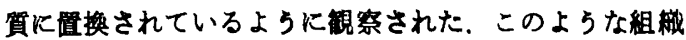
学的所見ならびに臨床像より，巨大型セメント贫通と考 えられた。

\section{考暴ならびにあとめ}

巨大型セメント資睡は，1961年 Gorlin')により初めて 提唱されたるので，1971年WHOの齿原性隀易の分類は によれば，七メント筫隀の中に分類されている．巨大型 セメント質腫は一般に，中年の黑人女性に多く認めら れ，両側性あるいは上下影の左右側に生じ，また，家族 性水発現することもあるため，家族性多発性セメント質 畽とす呼ばれている”。，その発現頻度は非常にまれで, 欧米ではいくつかの報告例了一つ) があるか，本邦において われわれが涉椫し得た笛围では，6 例の報告6 11)を見る にすぎず，そのため，臨床的に不明な点が多い，本症例 においては，家族性・多発性は否定されたか，臨床経過 が約40年と非常に長く，本疾患は爱徐に增大することを 示しているよらに思われる. 当然のことながら，本疾患 は歯牙組織にその発生源が求められ，それるセメント質 連はほとんどが萌出崡牙に関係して生しるとされ， Scannel ${ }^{12)}$ は，その発生原因について，炎症反応，外侮， 軽度の感染症，内分泌異常，ビタミン欠乏，全身的疾患 を挙げている。しかしながらこの点に関しては，不明 な点が多く，本症例においても，40年前の崡牙に関する 患者の記憶はあいまいであり，発生原因についてはより 一層不明確である.

病理組織学的には, 線維性組織がそしく，細胞封入の きわめて少ない塊状の原生セメント質が増形成され，こ れらが增大融合し，硬性睡慮を形成するとされている ${ }^{13}$, 14) ささらに, Pindborg ${ }^{15)}$ は, 本連瘤におけるセメント質 は大部分が無細胞性で，好塩基性の石灰化物からなり， 周囲の骨と容易に区別することができると述べている. 本症例では，へマトキシリンに好染する比較的均一な原 生セメント質類似の硬組織の増生を認め, 畽瘤の中心部 ではセメント小腔様構造が散見されたが，封入細胞は認 めなかった，一方，辺縁部では，骨・線維組織・脂肪組 織がセント質と混在し、骨・線䧽組織が中心部より辺 縁部にかけて徐々にセメント質に固換されていることが らかがえた。このよらな組織所見からは，腫煌珄增殖の 性格を汲み取ることはできず，本疾患を睡場に位着つけ ることは, 病理組織学的に議論の生じる所と思われる。 なお，X線所見および組織学的所見を考虑した時, 本例は Thoma \& Goldmann ${ }^{16)}$ のいらセハント質腫の発育段階 での最終段階すなわち Mature inactive stage が妥当と
思われる。

ところで，本例における処隹についてであるか，商临

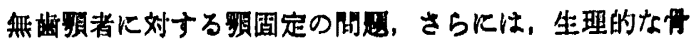

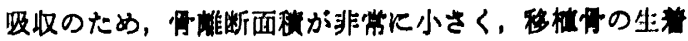

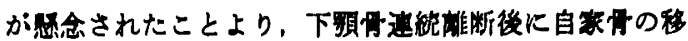
杜は行わず，A-O プレートによる速航固定を战みた。 幸いに，術後 1 年近く経過した現時点では止めネジの級 みはなく，绍過良好である。なお，本庆息の性格およひ

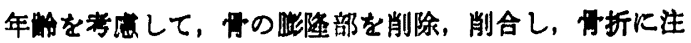
意を执いなから保存的に㽙察するのも一法であったかる しれない.

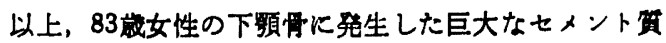

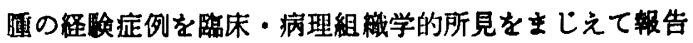
した.

本踰文の症例は，昭和61年 4 月，第 15 回日本口腔外科 学会中国・四国地方会で発表した.

\section{引用 文 献}

1) Pindborg, J. J. and Krammer, I.R.H.: Histological Typing of Odontogenic Tumors, Jaw Cysts, and Allied Lesions, International Histological Classification of Tumors. No. 5, WHO Geneva: 1-37 1971.

2) Gorlin, R.J.: Odontogenic tumors. Classification, histopathology, and clinical behavior in man and domesticated animals. Cancer 14: 73-101 1961.

3) John, S.C., Eugene, E.K., et al.: Gingantiform cementoma, report of two cases (mother and son). J Oral Surg 38: 65-70 1980.

4) Van der Waal, I. and van der Kwast, W.A.: A case of gingantiform cementoma. Int. J. Oral Surg 3: 44-444 1974.

5) Punniamoorthy, A.: Gingantiform cementoma, review of the literature and a case report. $\mathrm{Br}$. J Oral Surg 18: 221-229 1980.

6）鈴木三，小笠原佑吉，他 : Familial multiple cementoma (Gingantiform cementoma) の兄妹例 (抄). 日外誌 18: 653 1972 .

7）熊本順彦, 朝波忽一郎, 他：上買片側に多発した セメント質看の1例。日口外誌 20：458-461 1974.

8）岸本 源, 江口敏雄, 他：全影に発生した Gingantiform Cementoma の 1 症例. 日外誌 22: 875-879 1976.

9) 高井勇学, 水野治郎, 他 : 七メント質腫の 3 例. 口科誌 25：451-456 1976.

10）西嶋克巳，石田利広，他：顎骨に発生した多発性 セメント質腫の 2 例。 日口外誌 24：76-82 1978.

11）日高英治，藤原利彦，他：巨大型セメント質腫の 1 例（抄）。旦外誌 31：3016 1985. 
12) Scannel. J.M.: Cementoma. Oral Surg 2: 116911801949.

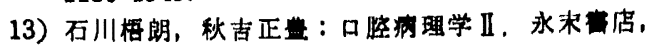
京都，1977，948-950面.

14) Gorlin, R.J. and Goldman, H.M.: Thoma's Oral Pathology I. 6 th Ed, Mosby Co, St Louis, 1970, p 503-506.
15) Pindborg, J.J.: Pathology of dental hard tissues. 1 st Ed, Munksgarrd Copenhagen, 1970, p 409-416.

16) Thoma, K.H. and Golodman, H.M.: Oral Pathology, 6 th Ed, Mosby Co, St Louis, 1950 , p 1301-1306. 